Viljar Veebel ${ }^{*}$

Baltic Defence College

Illimar Ploom ${ }^{* *}$

Estonian National Defence College

\title{
The Deterrence Credibility of NATO and the Readiness of the Baltic States to Employ the Deterrence Instruments
}

This current study aims to assess the credibility of the deterrence posture provided by NATO in avoiding Russia’s potential aggression against the Baltic countries; what could the aggression scenarios look like; what should be done to increase the credibility of NATO's deterrence strategy and the ability of the Baltic countries to employ additional deterrence instruments. The focus of the analysis is on four components: capability (both nuclear and conventional military capabilities), communication, cohesion, and interdependence/acceptance of norms. In this way, the authors build-up their own framework to cover both the physical capabilities of potential parties to the conflict and behaviouralethical aspects related to the current security environment. The article demonstrates the challenges for the Alliance's deterrence strategy and makes several suggestions of how to increase the credibility of NATO's deterrence strategy to avoid Russia’s potential aggression.

\section{Introduction}

Although according to the NATO's collective defence strategy, "no one should doubt NATO's resolve if the security of any of its members were to be threatened", ${ }^{1}$ while glancing at the North-Eastern flank of the Alliance, one cannot fail noticing that the Baltic states are in a perceivable, even if not immediate, danger. This makes one ask, does this mean that NATO's deterrence is not credible in the Baltics and not working for that particular region, or is the readiness of Baltic countries to employ NATO deterrence instruments also part of the problem?

\footnotetext{
"Dr. Viljar Veebel is a Fellow on Russian Strategic and Military Studies at the Baltic Defence College. Address for correspondence: Riia 12, 51013 Tartu, Estonia; phone: +372 717 6062; e-mail: viljar.veebel@ baltdefcol.org

"N Dr. Illimar Ploom is an Associate Professor of Strategic Studies at the Estonian National Defence College. Address for correspondence: Riia 12, 51013 Tartu, Estonia; phone: +372 717 6100; e-mail: illimar.ploom@ut.ee ${ }^{1}$ NATO, „Active Engagement, Modern Defence“, published on 23 May 2012. https://www.nato.int/cps/ua/ natohq/official_texts_68580.htm
}

DOI: 10.2478/lasr-2018-0007 
Indeed, the regional defence capabilities of the Baltic countries and their allies are questionable if compared with Russian capabilities in the region as well as their aggressive rhetoric. This amounts to the fact that the most visible and convincing part of deterrence available in this region in the present is deterrence by retaliation, not denial. Considering the fact that the talk is about NATO member states, why is an increase in the enhanced forward presence (eFP) troops of the allied forces in the Baltic countries and to station, for example, additional brigades from the U.S. with some solid air defence capabilities not included? This research argues that deterrence by retaliation is curiously also the one and most realistic model of deterrence at least in the mediumterm, as it would, de facto, concede Russia's interests in the Baltic region.

While the weaknesses of the current deterrence models may not be altogether as visible in case of the Baltics, the recent events in Ukraine and Georgia have revealed them. Without any overt fear of retaliation, we have seen Russia's aggression against its neighbours planned and executed with great sophistication, initiative, agility, and decisiveness. Indeed, Russia has avoided any moral hesitation. With these two countries, Russia has blatantly used the argument of "near abroad". In the international arena, there exists a political consensus about Russia having initiated a wave of hybrid warfare which is reflected on all possible levels and is constantly expanding in scope. Thus, drawing on the above, one could also conclude that Russia is, in a consistent manner, testing the credibility of the current international security framework and the principle of deterrence by searching for low-intensive options to destabilize neighbouring countries.

Due to common historical legacy and geographic proximity, the Baltic countries clearly constitute Russia's point of contact with NATO and are, therefore, also subject to the interests of Russia to test Alliance's capabilities. In this context, the aim of the article is to assess how credible is the deterrence posture provided by NATO in avoiding Russia's potential aggression against the Baltic countries, what could the aggression scenarios look like, and what should be done to increase the credibility of NATO's deterrence strategy to avoid aggression from the Russian side.

Additionally, this paper draws attention to the interwoven nature of both Russia and the Western world in the Baltics. When discussing the credibility of NATO's deterrence in the Baltics, Russia cannot be neglected. However, this topic is usually analysed in territorial terms, but it is equally important to acknowledge the civilizational or political aspect. The large share of Russian-speaking minorities, especially in Estonia and Latvia, have been under 
constant sophisticated pressure by the Kremlin. The Russian diaspora in the Baltics nevertheless represents only one aspect of a "wider game" conducted by the Kremlin to re-establish its position in the international arena.

Section 1 explains the essence of deterrence and discusses some theoretical dilemmas of building a viable deterrence model. Section 2 assesses the credibility of the strategy of deterrence within NATO's security framework in discouraging Russia's aggressive ambitions towards the Baltic countries. The analysis focuses here on the following components: capability, communication, cohesion, and interdependence/acceptance of norms. Section 3 proposes two hypothetical scenarios why, when, and how Russia would attack the Baltic countries and, based on the theoretical dilemmas and traps associated with the concept of deterrence, discusses some ideas about the priorities of the collective-actor deterrence in the changing security environment in Europe.

\section{Theory: Why Is It So Difficult to Build-Up a Viable Deterrence?}

In the academic literature, deterrence is summarised as an attempt to convince an adversary not to use military force, either by threatening retaliation (deterrence by punishment/retaliation) or by thwarting the adversary's operational plans (deterrence by denial). ${ }^{2}$ The fear of unaffordable consequences and the threat of use of force would discourage the opponent(s) and prevent or inhibit some actions which have not yet been initiated but which the opponent longs for. ${ }^{3,4,5}$ An aggressor is thereby persuaded by other actor(s) that aggression causes high costs and unacceptable damage which outweigh the potential gains arising from the conflict or aggression. ${ }^{6}$ Thus, deterrence is related to costs. Still, the costs may not be limited to material ones and may not occur immediately. For example, the "cost" could also be incurring, either

\footnotetext{
${ }^{2}$ Von Hlatky, S. „Introduction: American Alliances and Extended Deterrence“. In Von Hlatky, S., and Wenger, A. (eds.) The Future of Extended Deterrence: The United States, NATO, and Beyond, 2015. Georgetown University Press, p.3

${ }^{3}$ Keane, M. Dictionary of Modern Strategy and Tactics, 2015. Naval Institute Press.

${ }^{4}$ Zagare, F.C. Deterrence Theory. Oxford Bibliographies, 2013. http://www.oxfordbibliographies.com/view/ document/obo-9780199743292/obo-9780199743292-0161.xml

${ }^{5}$ Morgan, P.M. “The Concept of Deterrence and Deterrence Theory", 2017. Oxford Research Encyclopedias: Politics. http://politics.oxfordre.com/view/10.1093/acrefore/9780190228637.001.0001/acrefore9780190228637-e-572

${ }^{6}$ Paulauskas, K. “On Deterrence”, 2016. NATO Review Magazine. http://www.nato.int/docu/review/2016/ Also-in-2016/nato-deterrence-defence-alliance/EN/index.htm
} 
in terms of the loss of respect or credibility among certain groups in the future, the fear that something will happen, or the hopelessness to achieve something. Likewise, deterrence can be related to a belief that a certain technology will be developed and become available for use, or the emotional inability to leave the conflict.

Theoretically, deterrence is often associated with game theory models, combining expectations, availability of information, symmetry/asymmetry of mutual relations, and strategic decisions. In these models, the credibility of deterrence is largely determined by the previous "moves", the roles of the players, and their motivation. Game theory models which analyse the credibility of asymmetric deterrence presuppose that the higher the perceived probability that a player actually prefers to execute its deterrent threat, the higher the credibility of deterrence (see e.g. Zagare ${ }^{7}$ ). Intriguingly, according to some game theory models like the chicken game or the dollar auction game, being convincingly irrational and emotionally unstable could contribute to a faster deterrence of the opponent (see e.g. Veebel and Markus ${ }^{8}$ ). The theory of deterrence also contains a range of dilemmas that could lead to inefficient deterrence measures, the rise of tensions between opponents, and provocations with pre-emptive aggressive actions.

In this respect, the first dilemma is about choosing between strategies to escalate or de-escalate the conflict. Paradoxically, deterrence means that certain capabilities need to be demonstrated to the opponent while not revealing others. However, capabilities which are completely classified cannot often fulfil their deterring aims. The pre-emptive escalation of the conflict may deter or stop the opponents, given that they are following the ideas of offensive realism, arguing that states have to compete with each other for the power, but they are acting rational and, therefore, survival is their most important goal. ${ }^{9}$ So the result could be just the opposite, should the opponent be motivated by the idea of balancing, i.e. compensating, for the existing imbalance. ${ }^{10}$ In this case, the escalation of conflict is interpreted by the opponent as being provocative and hostile, requiring a response. In respect to the current analysis, this dilemma is mostly reflected in a situation where large-scale military capabilities, located

\footnotetext{
${ }^{7}$ Zagare, F.C. “Asymmetric Deterrence”, 1993, International Studies Quarterly, Vol. 37, p. 25. https://www. researchgate.net/publication/272587994_Asymmetric_Deterrence

${ }^{8}$ Veebel, V., Markus, R. "Will sanctions against Russia be successful: will Russia fall before Ukraine?”, 2016, Journal of Security and Sustainability Issues, Vol. 5 (4), p. 465.

${ }^{9}$ Mearsheimer, J., Conventional Deterrence, 1983. Ithaca, NY: Cornell University Press, p. 53. https://samuelbhfauredotcom.files.wordpress.com/2015/10/s2-mearsheimer-2001.pdf

${ }^{10}$ Levy, J.S. „Balances and Balancing: Concepts, Proportions, and Research Design“, 2003. In Vasquez, J. A., Elman, C. (eds.) Realism and the Balance of Power: A New Debate. NJ: Prentice Hall, pp. 128-153.
} 
in the Baltic region with the aim to deter Russia (e.g. deterrence by denial), are actually seen as being provocative from Russia's viewpoint, which may lead to conflict escalation.

The second dilemma concerns the balance between morality and efficiency. In more detail, one party to the conflict could easily find itself in a situation where it has to choose between a pre-emptive, decisive, independent action and passive status as a victim. Whereas the first may lead to a victory in a single battle yet risk losing the war, the second may bring short-term losses but nevertheless help to be successful in the conflict in general. In this light, a pre-emptive strike cannot be chosen, should it be more important for the party to the conflict to present itself as a non-aggressive "player", or victim, and to keep its morals high and sacrifice potentially some smaller losses. Under the current circumstances, whereas striking first would help the Alliance to keep its initiative during the conflict, it would also make NATO look highly aggressive, which contradicts the fundamentals of the Alliance.

Third, there is also a dilemma between prioritizing either strategic defences or deterrence. If deterrence is purely retaliatory, then its logic leads to a rejection of strategic defence, but if it includes denial, then it may well be logical to deploy strategic defences. ${ }^{11}$ One can detect a zero-sum game between these two options. While progress in terms of strategic defence contributes mostly to deterrence by denial, the funds allocated for strategic defences may well lead to a situation where investments into retaliation capabilities will be diminished, which in turn decreases the potential of the deterrence by punishment. The second aspect of this dilemma is related to a pragmatic choice of whether, overall, it would be more cost-efficient to rely on deterrence by punishment and to leave the country (or some of the allies) vulnerable to partial aggression, or to exploit the resources for deterrence by denial and avoid the aggression. In general, cost-efficiency of deterrence should be assessed rationally. This does not deny a possibility that should the aggressor act convincingly irrational, it would be difficult to assess its care about possibly incurring losses or damage by punishment. Moreover, there is no guarantee that more military forces or higher defence expenditures would make deterrence more credible. In this respect, a variety of systemic capabilities, as well as the applicability of various technologies, could play a much bigger role than, for example, the increase in the number of conscripts with an unknown ability of resilience and questionable kill-ratio. Accordingly, if the opponent's interests in achieving certain

\footnotetext{
${ }^{11}$ Buzan B. "Introduction: Deterrence and Defence". In An Introduction to Strategic Studies, 1987. International Institute for Strategic Studies Conference Papers, Palgrave Macmillan, London, p. 135.
} 
objectives are higher than one's own interests, deterrence may fail, which can also make big powers lose small wars.

Given the preceding discussion, the credibility of deterrence is clearly dependent on specific circumstances, yet, because of its controversial nature, it is difficult to assess under which circumstances and at which point of time deterrence becomes credible. In principle, we are studying something which is expected to never occur. This poses several methodological challenges, e.g. if deterrence is successful there is no behaviour to see; if deterrence fails, however, then behaviour does occur and can be observed; deterrence theory also fails because while all the conditions for deterrence are present, there is "no deterrence", 12 etc.

A number of factors have been suggested in the literature which could contribute to the credibility of deterrence. For example, van der Putten, Meijnders and Rood (2015) ${ }^{13}$ argued that:

to achieve effective deterrence, in addition to international cooperation, there are a few more conditions. The measures taken must be credible, the deterrence message must be clearly communicated to the potential perpetrator (communication), the threat and the actors from which it emanates must be known (intelligence), and the deterrence must be based on actual capabilities and an integrated approach.

So capabilities, communication, and integrity are relevant in terms of deterrence. Next to these three aspects, interdependence and acceptance of norms/taboos are also included in the analysis. This is borrowed from Glenn Snyder's approach to "broad deterrence", adding the mentioned two political elements to the deterrence (see: e.g. Snyder ${ }^{14} ; \mathrm{Nye}^{15}$ ). Due to various interdependences, a successful attack may cause serious costs to the victim as well as to the attacker, which means that a potential adversary may not attack even if there is no retaliation to be expected etc. (see: Keohane and $\mathrm{Nye}^{16}$ ). This is closely related to cyber threats: it has been argued that when collateral damage caused by cyberattack affects global banking or other shared infrastructure, it will also cause problems for the attacker and their allies, not merely for the in-

\footnotetext{
${ }^{12}$ Starr, H. "Cumulation, Synthesis, and Research Design for the Post-Fourth Wave". In Harvey, F.P. and Brecher, M. (eds.). Evaluating Methodology in International Studies (eds. Harvey, F.P.; Brecher, M.), 2005. The University of Michigan Press.

${ }^{13}$ van der Putten, F.; Meijnders, M.; Rood, J. Deterrence as a security concept against non-traditional threats: In-depth study, 2015. The Hague: Netherlands Institute of International Relations Clingendael. http://www.gsdrc.org/document-library/deterrence-as-a-security-concept-against-non-traditional-threats-in-depth-study/ ${ }^{14}$ Snyder, G.H. Deterrence and Defence, 1961. Princeton University Press.

${ }^{15}$ Nye, J.S. „Deterrence and Dissuasion in Cyberspace“, 2016. International Security, Volume 41, Issue 3, pp. 44-71.

${ }^{16}$ Keohane, R.O., Nye, J.S. Power and interdependence, 2011. Longman, 330 p.
} 
tended target. ${ }^{17}$ What needs to be taken into account are likewise reputational costs, resulting from infringing rules and norms, thus potentially deterring actions even if neither defence nor retaliation will follow. Nye ${ }^{18}$ argues that some degree of attribution is needed for norms to work. He also states that normative taboos may be relevant in cyberattacks. For example, developing a taboo not against types of weapons, but against certain types of targets. ${ }^{19}$ As will be seen, while the Kremlin has set its goal to shake the norms of the prevalent security regime, it is curiously also bound by them. Even if Russia is clearly not a supporter of the current regime content-wise, it still has, and has had, a tendency of trying to fit into the formal rules.

To sum up and provide an outline of the proffered research model, four components - capability, communication, cohesion and interdependence/ acceptance of norms - are selected as the basis for the following analysis to assess the credibility of NATO's deterrence strategy in discouraging Russia's potentially aggressive ambitions in the Baltic countries. Since the collectiveactor deterrence comprises both the deterrence provided by the alliance and by individual members of the group, ${ }^{20}$ these aspects are discussed from the point of view of both NATO and the Baltic countries. The choice of these components is based on the argument that under normal circumstances, one could presume that NATO could work out its capabilities on its own, solve coherence matters and execute unambiguous communication. Yet, the Alliance is not doing it because it admits to Russia having (legitimate) interests in "near abroad" regions. It means that the Alliance could not strengthen its presence in the Baltics fast enough to match Russia's capabilities. This, however, is not a one-way street. In order to understand the matter, especially as expressed by the presence of the large share of Russian-speaking minorities in the Baltic states, next to the trivial comparison of capabilities one needs to include other aspects such as interdependencies and acceptance of norms. This way the authors propose to combine the old model with a normative and ethical layer of deterrence. In terms of methodology, it means that an element of constructivism is included in the otherwise rationalist setting of traditional models like the $3 \mathrm{C}$ model or others. In this way, next to the comparison of both the nuclear and conventional capabilities of Russia and NATO, the cohesion of the Alliance (i.e. country-specific visions and perceptions), interdependence

\footnotetext{
${ }^{17}$ Jasper, J. „Deterring Malicious Behavior in Cyberspace“, 2015. Strategic Studies Quarterly, Spring. http:// www.airuniversity.af.mil/Portals/10/SSQ/documents/Volume-09_Issue-1/jasper.pdf

${ }^{18}$ Nye, J.S., 2017. Footnote 15.

${ }^{19}$ Nye, J.S., 2017. Footnote 15.

${ }^{20}$ Von Hlatky, S., 2015. Footnote 2.
} 
(i.e. mutual relations between Russia and the Alliance) and reputational costs incurred through infringement of rules/norms are discussed.

Given the preceding discussion, some limitations are also set on the current study with the aim to assess how credible the deterrence posture provided by NATO is in avoiding potential aggression on the part of Russia against the Baltic countries. First, as already mentioned, the authors are building-up a framework for the analysis to cover both the physical capabilities of potential parties to the conflict and behavioural-ethical aspects related to the current circumstances. Second, the study basically assumes that Russia's general aim is to devalue NATO's credibility and to increase Russia's negative "bargaining power" in the international arena, as well as to respond to any regional initiatives of the Alliance with its own respective activities and interventions. However, as far as particular risk is concerned that Russia could particularly attack the Baltic countries, the study focuses on the aim that Russia would like to restore control over the territory of the former Soviet Union, or at least to break off the relations of the Baltic countries with the Western world. This limitation seems to be reasonable in the way that it helps in the following sections to simulate the essence of the potential conflict situation in the Baltic region.

\section{Analysis: How Credible is NATO in Discouraging Russia's Regional Ambitions?}

\subsection{Comparison of Nuclear and Conventional Military Capabilities in the Baltic Region: NATO Versus Russia}

Although NATO nuclear policy has adapted to the changing strategic circumstances, nuclear aspects have still remained the least changed part of the Alliance's deterrence spectrum. ${ }^{21}$ Nuclear capabilities are considered to be integral to the strategy of deterrence of the Alliance ${ }^{22}$ and it is expected that the Alliance's nuclear weapons capabilities assure that any kind of aggression against its members is not a rational option. ${ }^{23}$ The Alliance's Strategic Concept states that:

\footnotetext{
${ }^{21}$ Kulesa, 1., Frear, T. NATO’s Evolving Modern Deterrence Posture: Challenges and Risks, 2017. ELN Issue Brief: Deterrence, May. https://www.europeanleadershipnetwork.org/policy-brief/natos-evolving-moderndeterrence-posture-challenges-and-risks/

${ }^{22}$ NATO's nuclear policy is based on NATO's 2010 Strategic Concept and the 2012 Deterrence and Defence Posture Review.

${ }^{23}$ NATO. „NATO's new Strategic Concept“, published on 25 November 2010. https://www.nato.int/cps/en/ natohq/news_68986.htm?selectedLocale $=$ en
} 
the supreme guarantee of the security of the Allies is provided by the strategic nuclear forces of the Alliance; particularly those of the United States; the independent strategic forces of the United Kingdom and France, which have a deterrent role of their own, contribute to the overall deterrence and security of the Allies. ${ }^{24}$

The Deterrence and Defence Posture Review, which was published in 2012, assessed that NATO's nuclear force posture met the criteria for an effective deterrence and defence posture. ${ }^{25}$

It is nevertheless relevant to note that some arguments have been highlighted in some analyses which refer to the vulnerability and weakness of the idea of nuclear capabilities being taken as a supreme guarantee of NATO's credible deterrence. First, the Alliance itself does not possess nuclear weapons and can't, therefore, provide either legal nor political assurances to its member or other states on how nuclear weapons belonging to the specific member states might be used. ${ }^{26}$ Moreover, among the owners of nuclear capabilities in NATO there is only partial consensus over the extent to which nuclear forces are "assigned" to NATO. Whereas the nuclear weapons of the UK have been formally assigned to NATO and the country has confirmed that the weapons will be used for the purpose of international defence of the Atlantic Alliance in all circumstances, the nuclear weapons of France are not assigned to NATO and are aimed to contribute to the overall deterrence and security of the Allies. Of course, France is also neither a member of NATO's nuclear structures nor does it participate in the Alliance's collective nuclear planning. There is also no consensus within NATO on the precise extent to which the US nuclear forces are assigned to NATO.$^{27}$ Second, nuclear issues are politically highly sensitive. Russia has used increasingly intimidating rhetoric, which creates concerns that it may lower the threshold for using nuclear weapons. ${ }^{28}$ The purpose of its rhetoric could be interpreted as preparing not only the international audience but its own population for a situation where there would arise a need to find a handy justification. It is noteworthy that Russia has already conducted some large-scale military exercises that included a simulation of a limited nuclear strike against the Alliance. The country has also invested in nuclear moder-

\footnotetext{
${ }^{24}$ NATO, „NATO’s nuclear deterrence policy and forces“, 2015, published on 3 December 2015, https:// www.nato.int/cps/en/natohq/topics_50068.htm

${ }^{25}$ NATO,. „Active Engagement, Modern Defence“, 2012. https://www.nato.int/cps/ua/natohq/official_ texts_68580.htm

${ }^{26}$ Chalmers, M. „Words That Matter? NATO Declaratory Policy and the DDPR“, 2011. NTI Analysis, http://www.nti.org/media/pdfs/NTI_Framework_Chpt2.pdf?_=1322701473

${ }^{27}$ Chalmers, M., 2011. Footnote 26.

${ }^{28}$ Rathke, J. „NATO's Nuclear Policy as Part of a Revitalized Deterrence Strategy“, 2016. CSIS, published on 27 January 2016. https://www.csis.org/analysis/nato\%E2\%80\%99s-nuclear-policy-part-revitalizeddeterrence-strategy
} 
nisation and exercises involving nuclear forces to send signals to NATO. This means that the overall vision of a nuclear disarmament deal has been pushed into the background. ${ }^{29}$ This could seriously endanger the respective international norms or amount to no lesser deed than breaking the taboos currently preventing the usage of nuclear weapons. Furthermore, several countries are making attempts to gain nuclear weapons capability. This causes political tensions and imbalances in the international arena and refers to the potential escalation and counterbalancing of nuclear weapons. Third, in practice, the role of nuclear weapons in the NATO doctrine has gradually decreased over the past two-three decades. If the number of US tactical nuclear weapons in Europe in the early 1990s was about 2,500, the figure has decreased since then and was 180 in 2016. Thus, should the US want to use these weapons, it would take weeks or even months to actually be able to do it. ${ }^{30}$

In that context, it is justified to ask for revision of policies and strategies related to nuclear deterrence of the Alliance. This issue has also been addressed in the most recent Nuclear Posture Review of the Department of Defence of the US from February 2018, referring to the rapid deterioration of the current threat environment and asking for initiation of the sustainment and replacement of the US nuclear forces. ${ }^{31}$ This step is highly important for the Alliance in general, because the nuclear capabilities of the US make essential contributions to the nuclear deterrence capabilities of the Alliance as a whole. Furthermore, the Review states that the United States will apply a tailored approach to effectively deter across a spectrum of adversaries, threats, and contexts, as well as that the United States will sustain and replace its nuclear capabilities, modernize NC3, and strengthen the integration of nuclear and non-nuclear military planning. ${ }^{32}$ However, it definitely takes both time and resources to achieve it. Under current circumstances, there may not be enough time for that, as Russia is already using a consistent strategy to "test the preparedness" of its neighbours and to initiate regional conflicts with an interval of only some years (i.e. in the Baltic region in 2007, in Georgia in 2008, in Ukraine in 2013, etc.)

The question whether nuclear weapons could be used in possible warfa-

\footnotetext{
29 „Bridging the Gap: Reviewing NATO's strategic posture and capabilities“, 2015. https://static.sdu.dk/ mediafiles/0/3/E/\%7B03E59EFA-0706-4961-A25A-D199A3994A34\%7DAgenda\%20NATO\%203-4\%20 December.pdf

${ }^{30}$ Sauer, T. „Just Leave It: NATO’s Nuclear Weapons Policy at the Warsaw Summit“, 2016. Published on Arms Control Association. https://www.armscontrol.org/print/7439

${ }^{31}$ Department of Defence. "Nuclear Posture Review: February 2018", 2018. p. 2. https://media.defense. gov/2018/Feb/02/2001872877/-1/-1/1/EXECUTIVE-SUMMARY.PDF

${ }^{32}$ Department of Defence, 2018, p. 4. Footnote 31.
} 
re scenarios in the Baltic countries has been addressed both in the political and military circles as well as discussed in many studies and reports. The report published by the RAND Corporation in 2016 argues that Russia's next most likely targets are the Baltic countries and that the nuclear forces of NATO do not have enough credibility to protect the latter. ${ }^{33}$ Thomson $^{34}$ suggests several reasons why the Baltic countries could be attacked by Russia, from the high strategic significance to the future disposition of the Baltic countries to the incorporation of new technologies into the forces of both Russia and NATO. Luik and Jermalavicius ${ }^{35}$ emphasise that Russia's political rhetoric includes nuclear threats towards the Baltic countries making them particularly vulnerable.

However, the authors of the current study disagree with the idea that the Baltic countries could be under potential nuclear attack, which could evolve to a nuclear war. This conviction relies on the argument that although both potential conflict parties, i.e. NATO and Russia, have striking capability, there exists no rational reasoning to execute a nuclear strike even as a measure of last resort. In fact, it is hard to believe in Russia having any rational motivation to use nuclear weapons in the Baltic countries while a large share of the population in the Baltic countries are Russian-speaking. Likewise, territorial proximity and Russia's most likely further ambition to legitimate the annexation come into play. However, the same arguments also refer to the fact that nuclear deterrence, which is considered to be a core component of NATO's credible deterrence strategy, does not provide any additional value for the Baltic countries either. On the one hand, there is a question of morality and escalation for the Alliance should NATO weigh using nuclear attack as a preventative measure. On the other hand, there are several logical gaps in the chain of argument justifying the Alliance to authorise usage of nuclear weapons against Russia in case the latter has fully or partially invaded the Baltic countries. First, there is a question of how could the strategic use of nuclear weapons against Russia be believable in a regional conflict? Second, how would it help to solve the conflict which has already started? Third, what would be the possible positive outcome for NATO, having initiated Mutually Assured Destruction with Russia to stop the occupations of Baltics?

\footnotetext{
${ }^{33}$ Shlapak, D. A., Johnson, M. W. Reinforcing Deterrence on NATO's Eastern Flank, 2016. RAND Corporation, https://www.rand.org/content/dam/rand/pubs/research_reports/RR1200/RR1253/RAND_RR1253.pdf ${ }^{34}$ Thompson, L. B. „Why The Baltic States Are Where Nuclear War Is Most Likely To Begin“, 2016. The National Interests, http://nationalinterest.org/blog/the-buzz/why-the-baltic-states-are-where-nuclear-warmost-likely-17044?page $=2$

${ }^{35}$ Luik, J., Jermalavicius, T. „A plausible scenario of nuclear war in Europe, and how to deter it: A perspective from Estonia“, 2017. Bulletin of the Atomic Scientists, Vol 73, pp. 233-239. http://www.tandfonline.com/ doi/full/10.1080/00963402.2017.1338014
} 
Intriguingly, it must be acknowledged that contrary to the just outlined arguments, the Baltic countries appear to be strongly convinced that NATO is ready to use nuclear weapons to protect the Baltic countries. Based on a survey conducted by the authors of the current research in Estonian military circles, ${ }^{36}$ it was relatively strongly believed that NATO is ready to use its nuclear weapons. The main argument consisted in a belief that without appropriate response, the Alliance will end its existence as a collective security network. Next to that, the respondents shared an understanding that the Russian leadership is convinced that NATO, and particularly the political leaders of the US, are determined to use nuclear weapons to defend the Baltic countries. At the same time, the Russian leadership was seen as not having a rational reason to use nuclear weapons capabilities against the Baltic countries and the NATO FP units. Equally, it is assumed that Russia is afraid to conduct a tactical nuclear strike in the region in order to avoid threatening and retaliation. These views appear to testify that, at least for the Estonians, nuclear deterrence remains an abstract concept without any profound strategic perception of how the nuclear deterrence would work in practice. From Russia’s perspective, its nuclear forces serve as a tool to achieve political objectives by intimidating its neighbouring countries and NATO allies. ${ }^{37}$ After Russia received a clear message from NATO's Warsaw Summit in 2016, and having thereafter witnessed the Alliance taking a significant step back in its nuclear language (see, Andreasen et al..$^{38}$ ), it is not excluded that the country interprets it as a message stating that the Baltic countries are not strategically important for the Alliance.

\footnotetext{
${ }^{36}$ To research country-specific positions towards nuclear deterrence, the representatives of the Estonian and Latvian military forces and civil servants of the Estonian and Latvian Ministry of Defence were interviewed to provide answers to the following questions: 1 . What is the importance of nuclear deterrence within your country's defence, deterrence and national security strategy? 2. To what extent are nuclear threats important within your country's assessment of the strategic environment when compared with other threats? 3. In your country's assessment, to what extent is the nuclear dimension central to NATO? 4. To what extent are nuclear topics a source of serious security concerns for your country? 5 . Is nuclear deterrence making Central and Eastern Europe more or less secure? 6. How does your country view the credibility of the US nuclear security guarantees, and has there been a debate on this issue since January 2017? 7. Is your country policy on nuclear issues significantly influenced by the position(s) of one or several other EU member states owning nuclear assets? 8 . What is your country's perception of Russia as a nuclear power? 9. The US has roughly 200 non-strategic nuclear weapons in Europe; Russia reportedly has 2,000 . Is this imbalance perceived as a security threat in your country? 10. Has there been any significant political debate in your country in favour of the hosting of the US nuclear weapons? In total, 26 military officers and public officials were interviewed: 14 in Estonia and 12 in Latvia in December 2017. The interviews were conducted in Tallinn, Tartu and Riga.

${ }^{37}$ Rathke, J., 2017, Footnote 28.

${ }^{38}$ Andreasen, S., Lunn, S., Williams, I. „Post-Warsaw analysis: What NATO said (or didn't say) about Nuclear Weapons“, 2016. NTI Analysis, http://www.nti.org/analysis/articles/post-warsaw-analysis-whatnato-said-or-didnt-say-about-nuclear-weapons/
} 
As far as conventional capabilities are compared, Russia has an unarguable conventional supremacy in the Baltic region. Shlapak and Johnson ${ }^{39}$ estimate that in a short-term (approximately 10 days), Russia could force 27 fully ready battalions (30-50,000 soldiers) equipped with armoured vehicles to an attack on the Baltics without needing to stop its military activities in Ukraine. NATO, on the contrary, will be able to immediately respond only with predominantly lightly armoured forces, consisting of the military forces of the Baltic countries and of a severely limited number of the military forces of the US and its partners. They suggest that, according to an optimistic estimate, NATO could deploy elements from 3 airborne infantry brigades, 1 Stryker brigade, and 1 US armor brigade. Hence, in the early stage of the conflict, Russia has advantages in tanks (7:1), infantry fighting vehicles (5:1), attack helicopters (5:1), cannon artillery (4:1), long-range rocket artillery (16:1), short-range air defence (24:1), and long-range air defence (17:1). Russia also has an advantage as far as the range of the cannon and rocket artillery and the range of the Multiple-Launch Rocket Systems are concerned..$^{40}$

If one assumea that in the early stage of a conflict between Russia and the Baltic states the resilience is mostly based on the local military forces of Estonia, Latvia, or Lithuania, the disproportion of conventional capabilities becomes even more apparent. In peacetime, the Latvian National Armed Forces should consist of 6,500 professional soldiers, 8,000 home-guards and 3,000 reserve soldiers. Alas, the number of combat-ready home-guards and reserve soldiers can be estimated at least half that given the still relevant conclusions of the State Audit Office in 2015 and the no-show high rate of the reserve soldiers for training. ${ }^{41}$ The Estonian armed forces include 5,700 professional, active servicemen (including active conscripts), 37,800 conscripts registered for compulsory military service, and 16,000 members of the voluntary Estonian Defence League. Latvia's wartime structure of the armed forces is considered to be approximately 17,500 men and women, ${ }^{42}$ whereas approximately

\footnotetext{
${ }^{39}$ Shlapak, D. A., Johnson, M. W., 2016. Footnote 33.

${ }^{40}$ Shlapak, D. A., Johnson, M. W., 2016. Footnote 33.

${ }^{41}$ Since the training of reserve soldiers has been reinstated in 2015, there have been numerous reports in the Latvian mass media on the high number of reserve soldiers not arriving for the training (in 2015, only 59 of 300 called-in arrived for the training and 168 out of 966 the year after) and fines imposed by Latvian courts on them, as well as the furore of many not being able to arrive due seemingly objective but formally unjustified reasons (Public broadcasting of Latvia 2017a). A reserve soldier is considered to be a former professional soldier or a former home-guard notwithstanding their length of service and military experience. Officers can be called-in for a maximum of 60 days per year, others for a maximum of 30 days annually (National Armed Forces of Latvia 2017a).

${ }^{42}$ The national defence concept, 2016. http://mepoforum.sk/wp-content/uploads/2017/01/Latvia-nationaldefence-concept-2016-en.pdf
} 
one-half to a maximum of two-thirds of that number is true in reality. Estonia's wartime structure of the armed forces is estimated to reach $60,000 .{ }^{43}$ The Lithuanian land forces currently consist of the Mechanized Infantry Brigade "Iron Wolf", the National Defence Volunteer Forces, the King Mindaugas Hussar, the Grand Duchess Birute Uhlan, the Lithuanian Grand Duke Butigeidis Dragoon Battalions, the Juozas Vitkus Engineer Battalion, and the Land Forces Juozas Lukša Training Centre, numbering about 3,500 regulars and civilians, and around 4,500 volunteers. ${ }^{44}$ However, as far as the structure of the Lithuanian land forces is concerned, reorganisations are scheduled for the next few years.

Considering the above, it is not surprising that the currently dominating belief in the Estonian military forces is that "the more, the better", having in mind more conscripts, more costs, more troops of the allied nations, etc. It is expected in political and military circles that this approach is making a potential opponent be more afraid. Yet, even if the Estonian defence model enables the mobilisation of a relatively large number of people, it is by its nature still fully non-aggressive, without any room for pre-emptive initiatives, extra territoriality or hybrid tools, not to mention the difference in scales and numbers compared to the Russian military forces. In this light, the conventional rebalancing is unachievable anyway. Moreover, the Estonian defence model (to be precise, also the Latvian one) does not involve independent retaliation capabilities, which could allure Russia to opt for painless testing-risking. Thus, it does not matter however advanced or extensive the static defence is, it could be expected that sooner or later the lack of retaliation motivates the opponent to test the actual survivability of the system.

To sum up, the conventional balance in the Baltic area is not achievable either for the Baltic countries in total nor even with the FPF battalions. Thus, the deterrence occurring from conventional capabilities is rather weak from the viewpoint of both NATO and the Baltic countries. The one and only argument which could partially speak in favour of credible deterrence in terms of conventional forces is that NATO has a much higher capability of additional deployment when sufficiently mobilized. Nevertheless, the effect could also be limited here should Russia believe that there exists a winning strategy for the country. This could mean that any attempt by NATO to balance conventional forces in the Baltic countries has not a deterring, but an outright escalatory effect. Shirreff predicts that according to the worst case scenario, Russia will

\footnotetext{
${ }^{43}$ „Estonian Defence Forces“, 2016. Estonian Defence Forces. http://www.mil.ee/en/defence-forces

${ }^{44}$ Lithuanian Armed Forces. 2017. https://kariuomene.kam.lt/en/structure_1469/land_force.html
} 
seize the territory of Eastern Ukraine, open up a land corridor to Crimea and invade the Baltic countries. ${ }^{45}$ Luik and Jermalavicius suggest that Russia's posture and capabilities could allow the country to seize its Baltic neighbours, establishing a relatively quick fait accompli that it then defends by issuing nuclear threats. ${ }^{46}$ Shalpak and Johnson estimate, on the basis of multiple game models, that the longest it could take Russian forces to reach the outskirts of the Estonian and/or Latvian capitals of Tallinn and Riga would be 60 hours. They argue that such a rapid scenario would leave the Alliance with only a limited number of options. ${ }^{47}$

\subsection{Different Visions and Perceptions of the NATO Member States and Cohesion of the Alliance}

The credibility of the Alliance's deterrence is at also risk because of the different visions of the NATO member states. They have different perceptions in terms of what should be the values, the focus, and the threat perceptions of the organisation, and whether Russia should be treated as a potential adversary. On the one hand, there are disagreements among the Allies about the core values such as democracy, rule of law, or value-based approaches to international politics, as well as concerns about the way how, for example, Turkey or the US prefer rather transactional or selective engagement with the NATO Allies. ${ }^{48}$ On the other hand, the balance between strengthening the positions on the Eastern flank of NATO has been called into question by a number of southern member states of the Alliance. In light of the Ukrainian conflict and Russia's aggressive ambitions, the organisation has, from the 2016 Warsaw Summit on, particularly strengthened its positions in the Northern and Eastern region, i.e. in the Nordic and Baltic countries. This has caused southern member states to express a concern that not enough, in financial terms, has been done to bolster their security. ${ }^{49}$ Furthermore, although the original aim of NATO does not comprise threats extending from mass migration, state collapse, or other developments, various global threats have still called into question the overall

\footnotetext{
${ }^{45}$ Shirreff, R. 2017 War With Russia: An urgent warning from senior military command, 2017. Published by Coronet.

${ }^{46}$ Luik, J., Jermalavicius, T., 2017. Footnote 35.

${ }^{47}$ Shlapak, D. A., Johnson, M. W., 2016. Footnote 33.

${ }^{48}$ Kulesa, L., Frear, T., 2017. Footnote 21.

${ }^{49}$ Dempsey, J. NATO's Eastern Flank and Its Future Relationship With Russia, 2017. Carnegie Europe. http://carnegieeurope.eu/2017/10/23/nato-s-eastern-flank-and-its-future-relationship-with-russiapub-73499
} 
narrative among the Alliance's member states what NATO should actually be deterring. For example, the most recent disagreement between the member states was between the US and Germany and France about whether the Alliance should be more substantially involved in the fight against the Islamic State in Syria.

Indeed, as stated by Kulesa and Frear, the different priorities of the Eastern and Southern flanks of NATO are not something new. ${ }^{50}$ Still, it seriously weakens the cohesion and solidarity of the Alliance and poses a threat to NATO's strategy of deterrence to work in practice.

The views of the Alliance's member states also differ in respect to Russia's possible aggression against the Baltic countries. Whereas the countries of the Eastern flank (mainly Estonia, Latvia, Lithuania, Poland, Romania, and Bulgaria) demand additional security guarantees in the form of an increased military presence and cyber deterrence, the position of some other member states, like Germany, Italy, and France, remains considerably vague as to whether Russia will actually attack the Baltic countries or not. ${ }^{51}$ This inevitably means that the views of the member states differ with regard to whether NATO's deterrence measures are already credible or not.

As far as the Baltic countries are concerned, NATO membership and the principle of collective defence based on Article 5 of the North Atlantic Treaty are considered to be the cornerstones of safeguarding security in Estonia, Latvia, and Lithuania, and of confronting potential existential threats from the Russian side. As a sign of their commitment to the Alliance, the countries have integrated their national defence capabilities into the collective defence network, participated actively in the Alliance's international missions and fulfilled their financial obligations to NATO. All these activities have undoubtedly contributed to the overall positive reputation of the Baltic countries in the Alliance, as well as increased the operational capability of the Baltics to function smoothly in NATO's joint collective defence framework as well as at the regional level. Neither aspect should be underestimated when assessing the credibility of NATO's deterrence strategy in the Baltic countries.

However, two aspects should be stressed when discussing the weaknesses of the current national defence models in the Baltic states as both could jeopardize the credibility of the deterrence strategy in the region. First, despite the fact that the views of the members of NATO differ in terms of Russia's ambitions in its neighbouring countries, the political and military elite of

\footnotetext{
${ }^{50}$ Kulesa, L., Frear, T., 2017. Footnote 21.

${ }^{51}$ Dempsey, J., 2017. Footnote 49.
} 
the Baltic countries are still strongly convinced that there exists a strategic consensus and integrity among the NATO member states, and also in Russia, in terms of the security guarantees granted to the Baltic countries. It can be said to boil down to a somewhat unrealistic belief that it will be possible to design a wider and more general concept of deterrence, which will be efficient and effective against every potential enemy, from political, economic, and social elite to military decision-makers.

Second, there is a significant obstacle which hinders the Baltic countries to fully exploit the gains of regional cooperation, to be mainly found in the different approaches and priorities to the development of national defence systems. For example, there is a lot of potential in joint procurements which are often cost-efficient. In 2001, Estonia and Latvia signed a joint contract with the company Lockheed Martin with the aim to purchase new "TPS-117" long-range radar systems to expand both countries' air surveillance capabilities. Yet, in recent years, Estonia has focused on joint procurements with other countries. In 2009-2010 a joint procurement for purchasing medium-range air surveillance radar systems was conducted with Finland to jointly purchase 14 medium-range air surveillance radar systems, "Thales-Raytheon Systems Ground Master 403", of which 12 are used in Finland and two in Estonia. The price of one radar system was 11.3 million euros and it has been estimated that, thanks to the joint procurement, the price of the equipment was about $50 \%$ lower than it would have been in the case of an independent procurement. Estonia is also currently considering joint activities with Finland and Norway. For example, following Finland's decision to purchase K9 self-propelled artillery and being aware of Norway's interest in buying these weapons, in Estonia joint training activities are considered to be held together with its partners, thus being able to reduce the life-cycle costs of the weapons and on maintaining the self-propelled artillery combined.

It must be admitted that, from a substantive point of view, the potential for regional cooperation is not too large. All three Baltic countries remain tiny in the international arena, even when combining their resources, which also means that joint procurements may not lead to remarkable material gains for them. However, this does not mean that immaterial aspects might not come into play. More precisely, Russia would definitely benefit from a situation where even the three small Baltic countries would be unable or unwilling to cooperate, which would refer to low coherence within the Alliance. Altogether, having in mind different priorities of the national defence systems, e.g. in Latvia and Estonia, the potential of joint military procurements in both countries 
seem to remain largely untapped, decreasing also the potential of a common deterrence strategy.

Finally, it is also worth mentioning that while analysing the first problem set outlined earlier a somewhat naive take of deterrence prevails among the local political and military elite in the Baltics. On the one hand, political statements in the Baltic countries explaining the role of the Alliance in protecting Estonia, Latvia, and Lithuania, to a large extent, rely on a rather illogical argumentation. It is asserted that should NATO decide not to protect the Baltic countries and not to respond to Russia's aggression, the Alliance would have to cease its activities, because nobody would be interested in joining the collective defence network anymore. Nonetheless, there are some traps in this logic: should Russia attack the Baltics, countries like Sweden and Finland are most likely even more motivated to exploit whatever security guarantees they can find in the international arena, including joining collective security networks such as NATO. Although Russia has heavily opposed the idea of Sweden and Finland being member states of NATO, referring to possible military measures from Russia's side to eliminate "that threat", ${ }^{2}$ and both countries also have long traditions of neutrality, this possibility should not be excluded due to rapidly changing security environments. In recent years, particularly in light of the Ukrainian conflict, both countries have already moved closer to NATO. For example, Sweden has signed a host-nation agreement that allows NATO forces to train in Sweden. The country is also actively participating in NATO military exercises like Baltic Operations and Steadfast Jazz. ${ }^{53}$ From time to time both countries also discuss the idea whether they should have even closer relations with NATO. Furthermore, it cannot be excluded that Sweden's and Finland's NATO membership would be a reasonable decision for these countries to get easier access to technological improvements in the military area.

On the other hand, what one must also see, especially when looking through the eyes of the Baltic leaders, the major player in NATO is the U.S. For the U.S., the possibility of not stepping forward and retaliating for a violation of sovereignty of NATO members would be an existential issue. From this perspective, there appears to be certain minimum levels of coherence. At large, i.e. about NATO in general, this is reflected in joint statements and actions. However, the core minimum cohesion of NATO can still be seen to depend on how the U.S. interprets the situation. Would the U.S. be willing to and capable

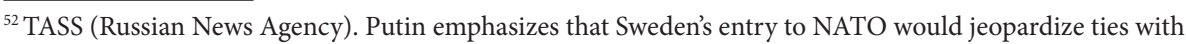
Moscow. 1 June 2017. http://tass.com/politics/949067

${ }^{53}$ Chang, F.K. Sweden's Foreign Policy: Nonaligned, But Not Entirely Neutral. Published on 2 November 2017. https://www.fpri.org/2017/11/swedens-foreign-policy-nonaligned-not-entirely-neutral/
} 
of protecting its allies, even the smallest ones? In this context, clearly the main strategy of the Baltics is to fully meet the requirements set by the U.S. and to seek for a special relationship with the U.S.

\subsection{The Strategic Communication: NATO versus Russia}

The strategic communication of the Alliance towards Russia has been mostly vague. It was mostly declared in the conclusions of the 2016 NATO Warsaw Summit that "we have decided to establish an enhanced forward presence in Estonia, Latvia, Lithuania, and Poland to unambiguously demonstrate, as part of our overall posture, Allies' solidarity, determination, and ability to act by triggering an immediate Allied response to any aggression" ${ }^{54}$ This refers to NATO's commitment to demonstrate its Allies' solidarity, as well as ability to act, by triggering an immediate response to any aggression. However, the Alliance does not seek direct confrontation with Russia ("The Alliance does not seek confrontation and poses no threat to Russia") and searches for a dialogue with Russia ("At the same time, as part of the Alliance's overall approach to providing security for NATO populations and territory, deterrence has to be complemented by meaningful dialogue and engagement with Russia, to seek reciprocal transparency and risk reduction"). Making the message even messier, the Alliance simultaneously states that no compromises are made with regard to the principles the organisation is relying on ("But we cannot and will not compromise on the principles on which our Alliance and security in Europe and North America rest."). ${ }^{55}$ In this way, the message of the Alliance as being an unprecedented defender of the NATO member states can be translated as weaker than the statements of Russia's political elite in constantly threatening both the member states of the Alliance and its partners.

Russia, by contrast, is constantly stressing that the expansion of NATO is considered as a threat. Similarly, Russia has heavily criticised any steps taken by the Alliance to strengthen its positions on the Eastern flank of NATO. For example, in Russia's most recent national security strategy, from 2016, the Alliance's activities were designated a threat to the country, referring to an "intensification of military activities of member countries", "moving military infrastructure closer to Russia's borders", a "further expansion of the Alliance" and "attempts to maintain the dominance of the US and its allies in global

\footnotetext{
${ }^{54}$ NATO, Warsaw Summit Communiqué, https://www.nato.int/cps/en/natohq/official_texts_133169.htm ${ }^{55}$ Ibidem
} 
affairs by carrying out a policy of containment of Russia". ${ }^{56}$ In its political statements, the country has not hesitated to use overtly aggressive rhetoric (Reuters $2016^{57}$ ), including the threats to use its nuclear forces as a tool to achieve political objectives. These are clearly aimed to intimidate opponents, to weaken the Alliance's cohesion, and to persuade NATO that Russia is ready to respond aggressively to any potential threat.

Next to that there is one more layer that needs to be briefly addressed at this juncture, even if it formally seems a rather minor aspect in this regard. We refer to the central role of the U.S. in the Alliance. As it was outlined in the previous subsection on coherence, the same issue plays a similar role here. As far as the North-Eastern flank of the organization is concerned, it is best visible in the statements of the President(s) of the United States. These statements are strong, and, most importantly, comparable in strength to those put forward by the Kremlin. In this sense the Baltic elites, as misguided in their understanding about theory of deterrence, may not be misled at all. As it was argued in the preceding subsection, the political and military elite of the Baltic countries are truly focusing on their mutual relationship with the U.S. The statements of the President of the U.S. are evaluated as being of the "hardest currency" of deterrence. Last but not least, it must be admitted that despite the problems with NATO communication in general, the U.S. nucleus dominates the table even here.

\subsection{Interdependence / Acceptance of Norms}

There have definitely been successful initiatives, like the establishment of the NATO-Russia Council (NRC) in 2002, in mutual relations between Russia and the Alliance. The NRC operates as a forum for dialogue and information exchange. But the relations have also witnessed serious setbacks, like the suspension of all actual cooperation with Russia, including the NATO-Russia Council, in 2008-2009 and in 2014-2015. Apart from this, political and military channels of communication were left open even when the NRC was suspended. ${ }^{58}$ After the deep freeze in relations with Russia at the peak of the Ukrainian crisis, the situation normalised again in 2016.

\footnotetext{
${ }^{56}$ Financial Times, „Putin names NATO among threats in new Russian security strategy“, 2016. Published on 2 January 2016. https://www.ft.com/content/6e8e787e-b15f-11e5-b147-e5e5bba42e51

${ }^{57}$ Reuters, „Putin says Russia taking 'countermeasures' against NATO expansion“, 2016. Published on 22 November 2016.

${ }^{58}$ NATO, „NATO-Russia Council“, 2017, published on 16 June 2017. https://www.nato.int/cps/ic/natohq/ topics_50091.htm
} 
In this sense, the first option of entanglement for NATO in deterring Russia would be to once again suspend the meetings of the NATO-Russia Council. However, two arguments speak against the credibility of this deterrence measure. First, at the 2016 NATO Warsaw Summit, the member states declared that the Alliance remains open to a periodic, focused and meaningful political dialogue with Russia on the basis of reciprocity. ${ }^{59}$ In this way, from a moral perspective, it would be difficult for NATO to take a step back and declare that there will be no further communication with Russia, especially when simultaneously declaring that Russia poses no threat to the Alliance. Furthermore, since in the relatively recent past NATO has suspended the meetings already twice without any tangible and long-term results, the Alliance's deterrence by entanglement becomes automatically weaker. Second, the NRC has already come under heavy criticism before the deterioration of mutual relations. It was argued that the forum has not been effective when dealing with the more sensitive and controversial issues which challenge the mutual relationship. ${ }^{60}$ Thus, Russian authorities seem to have very little to lose from deterrence by entanglement, especially after the case of Sergei Skripal and follow-up diplomatic reactions.

At this juncture another form of interdependence must be named, which could simultaneously encourage and deter Russia in threatening the Baltics, mainly the high share and concentration of a Russian-speaking population in the region under (potential) aggression. As straightforward use of military tools may be contra-productive to Russia's interest, the use of non-military tools of modern warfare such as disinformation and psychological pressure become valuable as they could ensure support of Russia's aggression at the local level.

In both of the most recent regional conflicts, i.e. when Russia torpedoed Georgia's efforts to move closer to the Western institutions of EU and NATO in 2008, and when they interfered in Eastern Ukraine to block the country's association agreement with the EU in 2013, Russia has relied on the argument of unacceptable conditions of Russian-speaking populations in these countries and exploited ethnic conflicts to escalate the conflict, particularly in Crimea.

For comparison, the number of inhabitants of Russian background is highest in Ukraine, covering almost 30 per cent of its population. However, the share of Russian minority differs significantly across the districts of Ukraine.

\footnotetext{
${ }^{59}$ NATO, „Relations with Russia“, 2017, published on 16 June 2017. https://www.nato.int/cps/ua/natohq/ topics_50090.htm

${ }^{60}$ Lunn, S., „The NATO-Russia Council: Its Role and Prospects“, 2013. ELN Policy Brief, November. https://www.europeanleadershipnetwork.org/wp-content/uploads/2017/10/The-NATO-Russia-CouncilIts-Role-and-Prospects_Simon-Lunn_November-2013.pdf.
} 
For example, approximately 60 per cent of the Crimean population were of Russian background and more than 70 per cent of the inhabitants of Crimea named Russian as their native language according to the Ukrainian National Census Survey in 2001. In Donetsk district, 38 per cent of the population were of Russian background and it is primarily Russian language that is spoken in the district. In Lugansk district, approximately 40 per cent of the population are of Russian background, and more than 68 per cent of the population consider themselves Russian-speakers. ${ }^{61}$ In South Ossetia and Abkhazia - the socalled frozen conflict zones in Georgia - the share of native Russians used to be relatively low before the war broke out in $2008 .{ }^{62}$ However, the Russian-related community in these regions is relatively big since, at the beginning of 2000s, Russia single-handedly extended Russian citizenship to the people living in South Ossetia and Abkhazia. This resulted in a situation where a majority of the population in these regions had dual citizenship before the outbreak of the military conflict in 2008. In this regard, it could be argued that at least in South Ossetia and Abkhazia, Russia had set the stage for the escalation of conflict over the past ten-fifteen years and has consciously contributed to the increase of its influence in the region.

In the Baltic region, the "argument of protecting Russian-speaking minorities" has been, to some extent, already tested in Estonia in 2007, when, after the relocation of a Second World War memorial dedicated to Soviet soldiers, the country faced extensive cyberattacks in a combination with violent actions organized by the local Russian-speaking community and backed-up by aggressive and accusative Russian media towards Estonia. Although the attackers could not be identified with absolute certainty, some of the internet addresses of the attackers pointed directly to Russian state institutions, and there is also evidence that local Russian-speakers had a role in the cyberattacks by instructing the others (see, e.g. Veebel $2016^{63}$ ).

Currently the number of the population with Russian citizenship, in comparison with total population of the Baltic countries in 2016, is indicated in Figure 1. The share of people with Russian citizenship is high in Estonia and Latvia (about 25\%), whereas in Lithuania it is relatively marginal (about 4.7\%). The role of the Russian-speaking community in the Baltic countries, and possible threats coming from this ethnic/linguistic group, have been increasingly debated and analysed in the region, particularly in Estonia, since

\footnotetext{
${ }^{61}$ Population Census Ukraine 2001. http://2001.ukrcensus.gov.ua/eng/results/general/nationality/

${ }^{62}$ Ministerstvo... 2015.

${ }^{63}$ Veebel, V. Estonia Confronts Propaganda: Russia Manipulates Media in Pursuit of Psychological Warfare. Per Concordiam, 2016c. 7 (1), 14-19.
} 
the events of 2007-2008. The results of the public opinion surveys on defence in Estonia show alarming signs in this respect, referring to a fundamental difference in opinions between the Estonian-speaking and foreign-speaking respondents on security and defence issues. More specifically, based on a series of public opinion polls administered in Estonia in 2014-2017, people were asked about important factors that would ensure maximum security to Estonia and approximately $2 / 3$, or even more, of the Estonian-speaking respondents named NATO membership, whereas less than $1 / 3$ of the foreign-speaking respondents agreed to that during the last three years. At the same time, a large majority of the foreign-speaking (predominantly Russophone) respondents strongly supported cooperation and good contacts with Russia (about 53-67\% of the foreign-speaking respondents). Only 13-23\% of the Estonian-speaking respondents agreed to that (see, Figure 2). It could be assumed that the difference is even more fundamental - whereas the Estonian-speaking community sees NATO, including the U.S., as a reliable ally and the foremost guarantee to the peace and security in the region, the foreign-speaking community are in favour of deepening the relations with Russia (see Figure 1). Thus, there exists a risk that these differences in opinions could grow into a larger conflict.

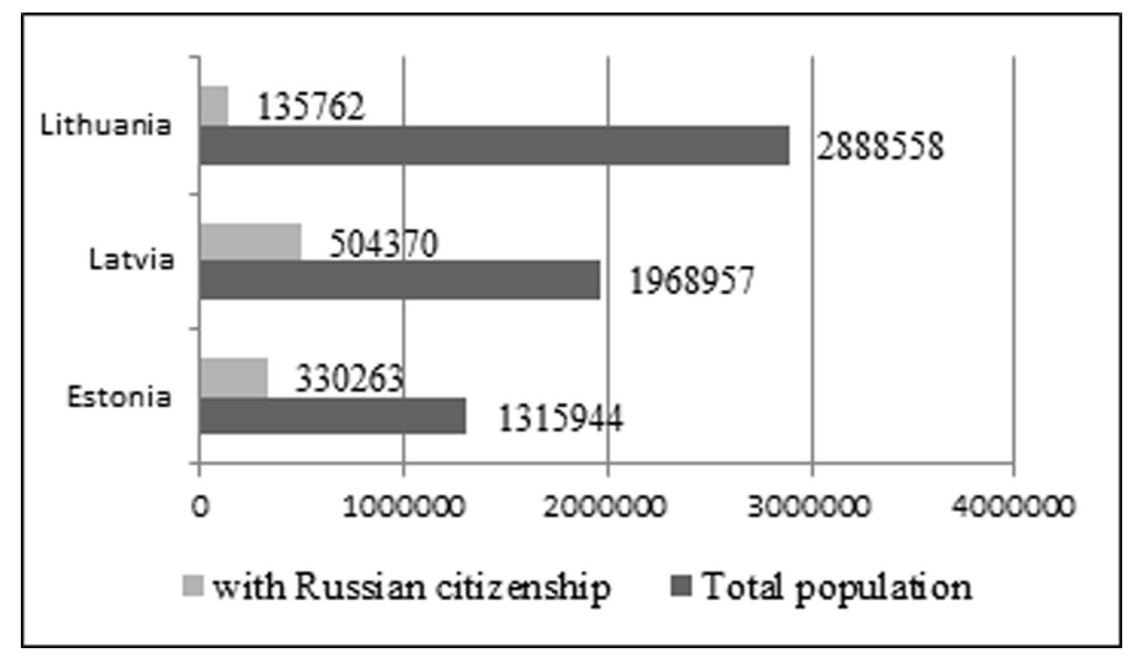

Figure 1. The number of the population with Russian citizenship and total population of the Baltic States in 2016 


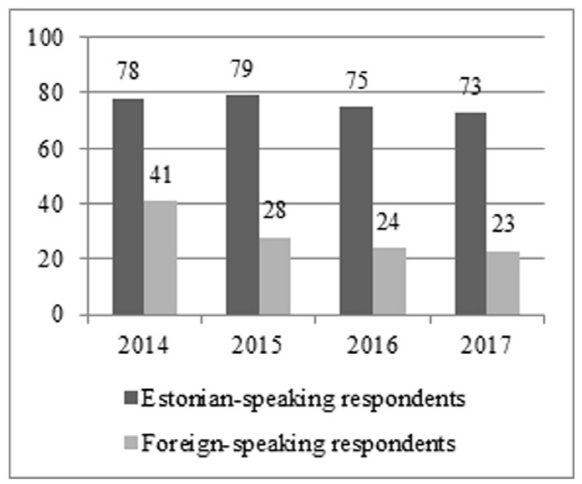

(a) Membership in NATO

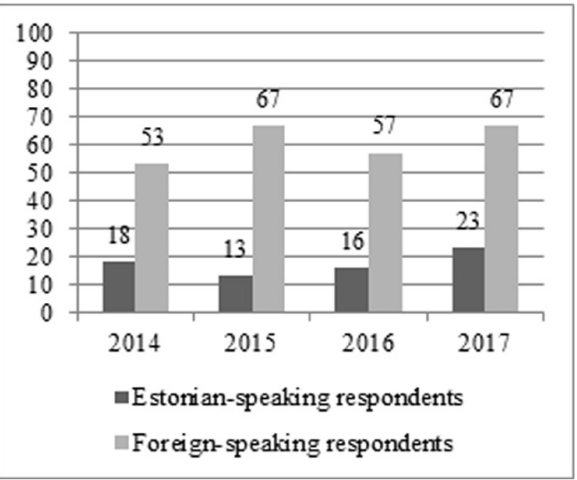

(b) Cooperation and good relations with Russia

\section{Figure 2. Responses to the question "Security guarantees for Estonia" 2014-2016:}

(\% of respondents of Estonian-speaking and foreign-speaking respondents, respectively) ${ }^{64}$

At the same time, the relatively large Russian-speaking community in Estonia and Latvia could partially work as a deterring measure. This is to refer to the discussion in Section 2.1.1, where the lack of rational motivation for Russia to use nuclear weapons in the Baltic countries was brought out, referring to the large Russian-speaking population in the Baltic countries.

As far as reputational costs incurred through infringement of rules and norms are concerned, Russia cannot be said to suffer much from a feeling of stigmatisation and reciprocity. On the one hand, since the beginning of the Ukrainian conflict, Russia has constantly sent signals to the international community that it willingly violates the fundamental principles of international law. It has also demonstrated that it is ready to combat the "unfair" measures of the international community against Russia, whatever the costs. ${ }^{65}$ On the other hand, while actively testing the low-intensity options for hybrid destabilization of the region, Russia simultaneously blames the Western countries for interfering in the home affairs of other countries. Likewise, as stated in Russia's most recent national security strategy from 2016, it sees the abuse of normative power in the international arena, referring particularly to the "attempts to maintain the dominance of the US and its allies in global affairs by carrying out a policy of containment of Russia”. To sum it up, although the international community has strongly condemned Russia for infringing international rules and norms, it has not succeeded to deter the country from destabilising its neighbouring countries.

\footnotetext{
${ }^{64^{*}}$ Source: Public opinion and national defence (2014), (2015), (2016), (2017).

${ }^{65}$ Veebel, V., Markus, R., 2016. Footnote 8.
} 


\section{Discussion and Conclusions:}

\section{Would It Be Possible to Increase the Credibility of NATO's Deterrence Strategy to Avoid Russia's Potential Aggression?}

The preceding analysis demonstrates the weaknesses of the Alliance's deterrence strategy. The overall idea of nuclear capabilities as a supreme guarantee of NATO's credible deterrence does not help to scale down Russia's regional ambitions. This is due to both morality arguments as well as practical reasons, such as territorial proximity of Russia and the Baltic counties, difference in opinions and priorities within the Alliance, potential for the escalation of conflict aspects, etc. Russia is justifiably considered to have conventional supremacy in the Baltic region. The conventional balance in the Baltic area is not achievable either for the Baltic countries in total nor with the FPF battalions, and the defence models of the Baltic countries are, by their nature, fully nonaggressive, without any room for pre-emptive initiatives, extra territoriality, or hybrid tools. What is more, as far as the Baltic countries are concerned, some signs of "self-deterrence" are also visible, referring to unsubstantiated, if not somewhat naïve, views of the political and military elite of the Baltic countries, as well as relying on so-called deterrence by imagination. The credibility of deterrence is at risk, depending on different visions of the Alliance's member states about what should be the values, the focus and the threat perceptions of the organisation, whether Russia should be treated as a potential adversary, or a somewhat vague response of the Alliance to Russia's political rhetoric. Similarly, the ethnic component - a relatively big Russian-speaking community, particularly in Estonia and Latvia - speaks mostly in favour of Russia in a potential regional conflict. It must be acknowledged that this could, to some extent, also have a deterring effect. Last but not least, as Russia is not suffering from a feeling of stigmatisation and reciprocity, the Alliance lacks tools that would have an entangling or disciplining effect.

To answer the question of what should be done in the future to actually deter Russia and to avoid aggression from the Russian side, the essence of the potential conflict should first be discussed. It is argued by this paper that the more precise the aim against whom, what, and when the deterrence is needed, the more cost-efficient the deterrence is.

Russia's past strategy against the Baltic countries can be judged as having been definitely well-thought, covering most of the escape routes for potential "victims". First, Russia has used the approach based on the Gerasimov doctri- 
ne which attempts to find a hybrid conflict model with a very low-intensity. Among other things, that would devalue the Alliance's credibility and allow an increase in Russia's negative "bargaining power" in the international arena by occupying part of the opponent's territory. Since the costs of this type of confrontation are low, Russia's destabilising attempts will most probably continue, i.e., at least as long as NATO will decide not to "punish" Russia. Second, Russia is simultaneously determined to respond to any regional initiatives of the Alliance with its own respective activities and interventions which have already led to a regional arms race. The reason why something like this has happened is the fact that Russia is strongly prioritizing national and emotional categories, whereas the current overall costs for the Alliance are low enough, giving no reason to worry yet. Also, even if the West contradicts the logic of the sphere of interests, the Baltic states, being situated in such proximity to Russia, are de facto considered as a zone where Russia needs to be allowed to retain high conventional advantage. Thus, any additional conventional defence measure applied on the Eastern flank of NATO could trigger an out-of-proportion arms-race or escalation from Russia. This dynamic is bound to work in Russia's favour, also in terms of providing ever more justification for its worries and possibly a pre-emptive attack.

Based on the past experience of Georgia and Ukraine, as well as Russia's past strategy against the Baltic countries, one hypothetical scenario why, when, and how would Russia attack the Baltic countries could be constructed. The most likely political aim of the potential aggression against the Baltic countries would be to restore control over the territory of the former Soviet Union, or at least to break off their relations with the Western countries. According to this logic, most of the energy will be invested into delegitimizing of local national political authorities by using the tools of hybrid warfare. Ultimately, this would lead to a situation where, disappointedly, the forces of the Alliance will decide to leave the Baltics. Russia's aim during such a takeover in the Baltic region would most likely be to maintain as many physical assets and legitimization as possible. This means it will need to avoid aggressive military activities. Also, since the Russian-speaking communities in Estonia and Latvia are relatively large, the takeover will have to take place without destroying much of the local infrastructure. However, the initiation of protests of "local women and children" against the "imperialists", including NATO, is highly likely. This draws on Russia's previous strategies used in Ukraine in 2014 and in Estonia in 2007. With a "little help" from Russia, this should not be too difficult, considering the public opinion of the local Russian-speaking community, at least in Esto- 
nia and Latvia. And, by the same token, the falling out of the Russian-speaking population will be exacerbated by the suspicious attitude towards the latter still prevalent among the Estonian and Latvian speaking communities. Here, the most effective deterrence key would be building a coherent and mutually respectful society. This presumes dealing rationally and systematically with the demographic outcomes of the occupation. Alas, the difficulty is the animosity from the different ethnic sides in these two countries. Returning to the hypothetical scenario, in recent years the Kremlin has tried its best to keep up the ill-feelings among the Baltic people and minorities. Due to the relatively messy political and social situations, the key element of Russia's strategy is focussed on the Baltic countries not even being able to recognise the beginning of the attack. This means that the latter will omit the opportunity to mobilize, both as far as the Baltic countries or the Alliance is concerned. Should the Baltic countries/Alliance still decide to mobilise themselves, Russia would describe it as an example of the opponent's aggressive behaviour, as well as a justification to interfere with the aim to protect the "peaceful local people".

Thus, there exists a potential for Russia to succeed in the Baltic region due to its conventional supremacy in the region, relatively radical views of local Russian-speaking communities, lack of the credible deterrence elements, etc. Next to the opportunity that it offers to Russia, according to the view of the authors, the attack against the Baltic countries could also be at least as strongly motivated by Russia's wish to ridicule the Alliance and the collective defence/deterrence network as a whole. Looking from this perspective, there exist many reasons why Russia would select the Baltic countries for this purpose. First, this could happen because of the logistical advantage for Russia. Russia has a land border with this region and the territories of the Baltic countries are also fully "covered" by Russia's anti-aircraft and missile defence systems. Second, as easy as it would be for Russia to bring additional military supplies to the Baltic region, the more difficult it would be to do so for the leading countries of the Alliance. Third, the relatively large Russian-speaking (and necessarily Russian-minded) community could be easily mobilised to justify and support Russia's aggressive ambitions in the Baltics.

The main reason why Russia could be successful in realising its aggressive ambitions in the Baltic countries is the tendency among the Baltic countries to think of their security and of deterrence based on rational logic (i.e. what would be reasonable risk and sacrifice to occupy the Baltics). At the same time, Russia is using both global and strategical scales where the limits for using its resources are only territorial as far as the Baltic countries are concerned. This 
means that Russia has, in principle, more resources available than it would be reasonable to maximally use to occupy the Baltic countries. Last but not least, Russia appears to also be ready to use these resources.

The difference in scale poses enormous challenges to NATO when thinking of how to avoid Russia’s further aggressive ambitions. Based on theoretical dilemmas and traps associated with the concept of deterrence as well as taking into account country-specific circumstances, the authors would like to discuss some ideas about the priorities of both the Baltic region and the collective-actor deterrence network in changing the overall security environment in Europe.

First, a more proactive strategy is needed in NATO on how to resist and control Russia's potential aggressive outbreaks against small member states of the Alliance. Otherwise, the victims of Russia's potential aggression will be bound to lose in all circumstances. That is, either when they reasonably prepare against local threats which, nonetheless, is strategically insufficient, or when they try to deter Russia with all possible means and resources which cannot obviously be sustainable even in the mid-term, given both their limited economic resources and small populations. Therefore:

- The first precept is that the Baltic countries should not be afraid to clearly set out and express the view in the Alliance that Russia's regional aggression against the Baltic countries would, in real terms, not be triggered and caused by themselves in terms of the mistakes the Baltic counties have made, but by Russia's ambition to actively oppose NATO.

- Resilience should not be considered as the primary component of deterrence in NATO against Russia's aggressive ambitions in the Baltic countries, because Russia is able to quickly mobilise and use a large amount of Anti-Access Area Denial (A2AD) capabilities to foreclose access to the resources of the Alliance. It has to lay emphasis on punishment or retaliation that follows the initiation of the aggression.

- In this light, a common consensus needs to be achieved among the Baltic countries that, just like regional tensions and arms races have not emerged due to regional incentives, they are not to be solved at the regional level by the countries located in the periphery. Furthermore, to communicate this view in a coherent manner at the level of NATO will be the main challenge for the Baltics in the coming years. In other words, one condition of Russia's strategic aim would be to discredit the Alliance and it selects the Baltic countries as the best location for executing its plan, it implies that any possible local efforts to create deterrence cannot be successful. 
- In this respect, the key concern today is that the Baltic countries prepare themselves against a local scenario. At the same time, Russia makes preparations to teach the Alliance a lesson at the strategic level.

By contrast, with all probability, the Baltic countries will be able to mitigate the risks using the so-called local motivation against Russia's aggression. The context here is the second scenario proposed earlier, which describes how local social and political tensions in the Baltic countries could be exploited to draw them from the Euro-Atlantic partnership into the Russia's sphere of influence. Three types of measures are particularly important in this respect.

- First, political resilience should be increased, allowing the Baltic countries to adopt rapid countermeasures in case of Russia's aggression. This would not allow Russia to use the strategy of low-level aggression. In this case, the main hope for the Baltic countries consists in Russia giving up the aggression in the middle of the conflict after seeing that the model of "a peaceful liberator" would not work in the Baltics.

- Second, to avoid social discontent in the society, which would work in favour of Russia in case of the conflict, attention should be directed towards both social inclusion and social welfare of the local people in Estonia, Latvia and Lithuania. This applies particularly to those regions of the Baltic countries with a high share of Russian-speaking population.

- Third, the Baltic countries need to make the most of the potential added value arising from both joint planning activities and the common use of resources. The ability to conduct joint procurements and to jointly train, plan, and make decisions needs to be increased. And the increased joint capabilities and abilities need to be openly demonstrated to Russia. The already existing joint capabilities need to be coordinated at the regional level. Thus, instead of determining and meeting the narrow national defence, a clear focus on the regional level is needed. In this regard, problems in one of the Baltic countries in developing its military resources are, and should actually be, a common concern for all three Baltic countries together. Should this idea of joint efforts be not quickly enough be learnt, help should be provided from NATO, which could give politicians instructions of how to jointly plan, train, and develop military capabilities.

Last but not least, the Alliance could also make some significant efforts to increase the credibility of its strategy of deterrence. For example, it is obvious that Russia is not underestimating the role of explicit strategic communication in determining the outcome of the conflict. The tactic of the Kremlin is to mobilize people using emotional arguments (more or less "we are under attack 
and everybody wants to destroy us"). The same approach would most likely not work in the case of the Alliance, because NATO is highly unlikely to be able and willing to emotionally mobilise and oppose itself to Russia. This is due to the differences among the NATO member states in the way they see Russia's ambitions and actions in the current security environment. An alternative option for NATO to increase the credibility of its political statements - which would also mean an increase to the credibility of the Alliance's deterrence strategy - would be to rely on rational arguments whereby it explains, in a simple manner, why it would be easier and cheaper for NATO to defend the Baltic countries in comparison to what it would take to liberate them.

February 2018 